\title{
Microbiological quality analysis of fresh vended fruit juices and water sold in roadside stalls in Dhaka Metropolis by MPN method
}

\author{
Mahamuda Akther Eva, Shawda Shafiq Shreya and Tasnia Ahmed* \\ Department of Microbiology, Stamford University Bangladesh, 51 Siddeswari Road, Dhaka 1217, Bangladesh
}

Received 03 February 2017/Accepted 17 March 2017

\begin{abstract}
Quality of drinking water and juice is very important because if the quality deteriorates by the contamination of faecally originated microorganisms, it may cause serious diarrhea associated problems leading to death. In overpopulated countries like Bangladesh, this is a common scenario to experience diarrheal diseases due to drinking non-potable water as well as contaminated fresh juices. Present study was conducted to determine the quality of drinking water and juice by detection of indicator bacteria Escherichia coli by MPN (Most Probable Number) method which was performed by three consecutive steps including presumptive test, confirmed test and completed test. Other gram negative bacteria were also identified by biochemical methods. The indicator bacterium Escherichia coli was detected in two water samples out of 15 samples and one juice sample out of fifteen samples respectively during the MPN test method. Other Gram negative bacteria found in both water and juice samples included Klebsiella spp., Alcaligenes spp., Pseudomonas spp. and Proteus spp. The quality of drinking water and juice was found to be good in Bangladesh but proper hygiene should be maintained more strictly to avoid the contamination by other gram negative bacteria which are also capable of causing disease.
\end{abstract}

Key words: Fruit juice; Drinking water; Most Probable Number (MPN); Quality; Portability

Water is one of the five major dietary components required for good health of human. Though water is one of the most abundant components found in the environment but the availability of pure drinkable or potable water is a matter of question nowadays due to overpopulation, unhygienic living conditions, pollution, damage of ecosystem, destruction of the environment by human activities, changing weather etc. (1-3). Water plays an important role in regulating metabolic activity as well as maintain physiological activities but at the same time can cause disease if consumed focally contaminated water (4-5). According to World Health organization, every year approximately four billions cases of diarrhea with few millions of enteric diseases occur due to drinking non potable water (6). Underground water supply is usually free from microbial contamination, but it can occur by nearby overflowed sewage line, underground leakage from sewage line and cause serious health associated problems $(1-4,7-9,10,11)$. Majority of people in Bangladesh drink water directly after collecting from pump or some processing like filtering, boiling, chemical treatments etc. (1-3). Contamination by human and animal waste can serve a source of pathogenic bacteria causing different diseases like

*Corresponding Author: Mailing address. Tasnia Ahmed, Lecturer, Department of Microbiology, Stamford University Bangladesh, 51 Siddeswari Road, Dhaka 1217, Bangladesh, Bangladesh; E-mail: tasnia2009@yahoo.com. dysentery, diarrhea, typhoid, salmonellosis, shigellosis, listeriosis, viral infections like Hepatitis A, parasitic infections and so on (12-16). Some pathogenic microorganisms contaminating the water include Salmonella spp., Escherichia coli, Listeria spp., Shigella spp., Vibrio spp., Yersinia spp., Campylobacter spp., Hepatitis A and Hepatitis E virus, some parasites etc. (1719). On the other hand, fruit juices are non-alcoholic beverages which are very popular among the people of all ages, especially in summer season. Health conscious people these days prefer fresh juices more than soft drinks. They supply vitamins and minerals (calcium, phosphorous, sodium), bioactive compounds (glycosides, flavanone antioxidants hydroxycinnamic acid) which help to improve human health status, helps in maintaining blood lipid profile in patients suffering from hypercholesterolemia, inhibit breast cancer, defeat urinary tract infections, give protection from congestive heart failure (20-27). Juices are prepared by squeezing the fruit pulp and mixing it with significant amount of water, ice, syrup and other ingredients depending on the recipe (28). Contaminated fruit juice can be responsible for gastrointestinal disorders and even death if consumed (29-37).

The easiest way to determine the quality drinking water is to detect the indicator bacteria Escherichia coli in the water as well as fruit juices which determines the equivalent presence of focally contaminated other pathogenic bacteria which are difficult to culture and also 
present in very low numbers (38-40). One easy method to detect the indicator bacteria Escherichia coli from the water sample is MPN method which is also known as multiple tube method comprising three consecutive tests as presumptive test, confirmed test and completed test (41-43). Present study was designed to determine the quality of drinking water and fruit juices available in roadside tea stalls in Dhaka Metropolis. Fifteen water samples and fifteen fresh fruit juice samples were collected randomly from different areas of Dhaka city for microbiological quality analysis by most probable number (MPN) technique.

\section{MATERIALS AND METHODS}

Study area and sample processing. Fifteen fruit juice and fifteen water samples were collected from different areas of Dhaka city. After aseptically collection of samples, the samples were transferred immediately to the laboratory for microbial quality analysis by following the procedures proposed by American Public Health Association. (43).

MPN test procedure

Presumptive test. Presumptive test is the primary presumption for the presence of Gram negative coliform bacteria in the samples which can be detected by the appearance of gas in the Derhum tubes placed inside the lactose broth of $1 \mathrm{x}$ concentration) is required for each sample under analysis. Each test tube contained $10 \mathrm{ml}$ of fermentation broth and inoculated with the juice and water samples individually in a sequential order of $10 \mathrm{ml}$ in five of each $2 \mathrm{X}$ lactose fermentation broth, $1 \mathrm{ml}$ in five of each $1 \mathrm{x}$ lactose fermentation broth and finally $0.1 \mathrm{ml}$ in five of each $10 \mathrm{ml} 1 \mathrm{X}$ lactose fermentation broth. All the test tubes were incubated with half circled screw caps at $37^{\circ} \mathrm{C}$ for 48 hours. By this procedure all of the 15 samples were subjected to the presumptive test individually (1-2).

Confirmed test. Positive samples indicated by the production of gas in the Durham tubes placed inside the lactose fermentation broth were selected for the confirmed test procedures to determine whether the indicator bacteria of fecal origin Escherichia coli was present or not. One loop full sample from the positive test tubes was inoculated on EMB by streaking and incubated at $37^{\circ} \mathrm{C}$ for 24 hours and then observed for the production of green metallic sheen. EMB media was used as differentiate media to detect and separate Escherichia coli from other Gram negative coliform bacteria by the production of green metallic sheen in the media. The presence of green metallic sheen in EMB confirms the presence the indicator bacteria E. coli. (1-2).

Completed test From the green metallic sheen showing streaking line produced by E. coli on EMB media was inoculated into LFB $1 \mathrm{X}$ media containing Durham tube to re-confirm the positive lactose fermentation by the detection of gas. From the same place of EMB media, E. coli inoculum was taken to observe microscopically for their Gram reactions. This was the final stage of the MPN method where we can decide that whether the juice under analysis was potable or not. Finally, the standard biochemical tests were performed to confirm the identification of isolates other than Escherichia coli found on EMB agar plates for all of the 15 of fruit juice samples by the standard biochemical tests (43-44).

Identification of other bacteria found on EMB. To determine the presence of other gram negative bacteria, the inoculum from the growth on EMB media were subjected to biochemical identification.

TABLE 1. Presumptive test results for juice

\begin{tabular}{|c|c|c|c|c|c|c|}
\hline Sample & $\begin{array}{c}5 \text { of } 10 \mathrm{ml} \\
\text { each }\end{array}$ & $\begin{array}{c}5 \text { of } 1 \mathrm{ml} \\
\text { each }\end{array}$ & $\begin{array}{c}5 \text { of } 0.1 \mathrm{ml} \\
\text { each }\end{array}$ & MPN/100ml & $\begin{array}{c}\text { Lower limit of } 95 \% \\
\text { confidence }\end{array}$ & $\begin{array}{c}\text { Upper limit of } 95 \% \\
\text { confidence }\end{array}$ \\
\hline 01 & 2 & 0 & 0 & 5 & $<0.5$ & 13 \\
\hline 02 & 4 & 4 & 1 & 21 & 7 & 42 \\
\hline 03 & 5 & 5 & 3 & 920 & 220 & 2600 \\
\hline 04 & 5 & 5 & 5 & $\geq 2400$ & 700 & 0 \\
\hline 05 & 5 & 5 & 5 & $\geq 2400$ & 700 & 0 \\
\hline 06 & 5 & 5 & 3 & 920 & 220 & 2600 \\
\hline 07 & 5 & 5 & 5 & $\geq 2400$ & 700 & 0 \\
\hline 08 & 5 & 5 & 3 & 920 & 220 & 2600 \\
\hline 09 & 5 & 5 & 5 & $\geq 2400$ & 700 & 0 \\
\hline 10 & 5 & 5 & 3 & 920 & 220 & 2600 \\
\hline 11 & 2 & 0 & 1 & 7 & 1 & 17 \\
\hline 12 & 4 & 0 & 0 & 13 & 4 & 35 \\
\hline 13 & 1 & 0 & 0 & 2 & 0.3 & 10 \\
\hline 14 & 2 & 0 & 0 & 5 & $<0.5$ & 13 \\
\hline 15 & 5 & 3 & 2 & 140 & 52 & 400 \\
\hline
\end{tabular}

TABLE 2. Presumptive test results of water

\begin{tabular}{ccccccc}
\hline Sample & $\begin{array}{c}\mathbf{5} \text { of 10 } \mathbf{~ m l} \\
\text { each }\end{array}$ & $\begin{array}{c}\mathbf{5} \text { of } \mathbf{1} \text { ml } \\
\text { each }\end{array}$ & $\begin{array}{c}\mathbf{5} \text { of 0.1 } \mathbf{~ m l} \\
\text { each }\end{array}$ & MPN/100ml & $\begin{array}{c}\text { Lower limit of 95\% } \\
\text { confidence }\end{array}$ & $\begin{array}{c}\text { Upper limit of 95\% } \\
\text { confidence }\end{array}$ \\
\hline 01 & 5 & 5 & 5 & $\geq 2400$ & 700 & 0 \\
02 & 5 & 5 & 5 & $\geq 2400$ & 700 & 0 \\
03 & 5 & 5 & 5 & $\geq 2400$ & 700 & 0 \\
04 & 5 & 5 & 4 & 1600 & 400 & 7600 \\
05 & 5 & 5 & 1 & 350 & 100 & 10 \\
06 & 1 & 0 & 0 & 2 & 0.3 & 120 \\
07 & 5 & 1 & 1 & 46 & 14 & 400 \\
08 & 5 & 4 & 0 & 130 & 36 & 7000 \\
09 & 5 & 5 & 4 & 1600 & 400 & 17 \\
10 & 5 & 0 & 0 & 23 & 7 & 35 \\
11 & 2 & 0 & 1 & 7 & 7 & 120 \\
12 & 3 & 1 & 0 & 11 & 5 & 4600 \\
13 & 5 & 1 & 1 & 46 & 14 & 22 \\
14 & 5 & 5 & 4 & 1600 & 400 & 2 \\
15 & 3 & 0 & 0 & 8 & & \\
\hline
\end{tabular}




\section{RESULTS AND DISCUSSIONS}

Food borne infections and intoxications are very common in developing countries like Bangladesh (4550). Quality of drinking water and juice is very important because it directly influences the health status of a particular locality. Juices can transmit pathogenic microorganisms which can be incorporated by different ways like raw materials used in juice preparation (water, ice which are main source), fruit quality, equipment and hygiene of preparation area as well as the juice makers (51-55). On the other hand, water is not only used directly for drinking but also for other purposes like cleaning, washing, food preparation, juice and other drinkable item preparation, cooking, maintaining proper hygiene and so on. The contaminated water with pathogenic bacteria can come from fecal contamination and transfer to human by fecal oral route and cause serious enteric diseases. has been found out that each year 2 million death occurred due to enteric diseases resulting from contaminated drinking water $(7,15)$. The problem is more common in densely populated country including Bangladesh where the maintenance of proper hygiene, processing a huge quantity of water for drinking and maintain proper disposal of sewage waste which might increase the contamination rate as well as diarrheal incidents $(1-3,10,15)$.

Current study was conducted to determine the quality of fresh fruit juices and water by most probable number (MPN) method which only target the presence of indicator coliform bacteria Escherichia coli. If this bacteria is present in the juice then it could be assumed that the quality of juice is not good and it is non-potable. The contamination might come from the water and ice used in the juice preparation.

In presumptive test, four juice samples (sample no. 4, 5, 7 and 9) showed maximum growth of lactose fermenting coliform bacteria with the $\geq 2400$ MPN $/ 100 \mathrm{ml}$ juice (Table 1). Second highest growth was present in sample

TABLE 3. Confirmed test results of juice

\begin{tabular}{ccccc}
\hline Sample no. & $\begin{array}{c}\text { Growth of coliform on } \\
\text { EMB media }\end{array}$ & $\begin{array}{c}\text { Production of green } \\
\text { metallic sheen }\end{array}$ & $\begin{array}{c}\text { Presence of } \\
\text { Escherichia coli }\end{array}$ & Result \\
\hline 01 & Present & Negative & Absent & Potable \\
$\mathbf{0 2}$ & Present & Positive & Present & Non-potable \\
03 & Present & Negative & Potable \\
04 & Nresent & Negative & Absent & Potable \\
05 & Present & Negative & Absent & Potable \\
06 & Present & Negative & Absent & Potable \\
07 & Present & Negative & Absent & Potable \\
08 & Present & Negative & Absent & Potable \\
09 & Nresent & Negative & Absent & Potable \\
10 & Present & Negative & Absent & Potable \\
11 & Present & Absent & Potable \\
12 & Present & Negative & Absent & Potable \\
12 & Present & Absent & Potable \\
13 & Present & Negative & Absent & Potable \\
14 & Present & Negative & Absent & Potable \\
15 & Present & & & \\
\hline
\end{tabular}

TABLE 4. Confirmed test results of water

\begin{tabular}{ccccc}
\hline Sample no. & $\begin{array}{c}\text { Growth of coliform on } \\
\text { EMB media }\end{array}$ & $\begin{array}{c}\text { Production of green } \\
\text { metallic sheen }\end{array}$ & $\begin{array}{c}\text { Presence of } \\
\text { Escherichia coli }\end{array}$ & Result \\
\hline 01 & Present & Negative & Absent & Potable \\
02 & Present & Negative & Absent & Potable \\
$\mathbf{0 3}$ & Present & Positive & Present & Non potable \\
04 & Present & Negative & Absent & Potable \\
05 & Present & Negative & Absent & Potable \\
06 & Present & Negative & Absent & Potable \\
07 & Present & Negative & Absent & Potable \\
08 & Present & Negative & Absent & Potable \\
09 & Present & Negative & Absent & Potable \\
10 & Present & Negative & Absent & Potable \\
11 & Nresent & Negative & Absent & Potable \\
12 & Present & Negative & Absent & Potable \\
13 & Present & Positive & Present & Potable \\
$\mathbf{1 4}$ & Present & Negative & Absent & Non potable \\
15 & Present & & & Potable \\
\hline
\end{tabular}


no. 3,6, 8 and 10 with $920 \mathrm{MPN} / 100 \mathrm{ml}$ juice sample. Lowest number of coliform bacteria with lactose fermenting capability was present in sample no. 13 (2 MPN/100ml juice).

In the same step for water test, three water samples (sample no. 1, 2, 3) showed maximum growth of lactose fermenting coliform bacteria with the $\geq 2400$ MPN/100ml water (Table 2). Second highest growth was present in sample no. 4, 9 and 14 with 1600 MPN/100ml drinking water. Lowest number of coliform bacteria with lactose fermenting capability was present in sample no. 6 (2 MPN/100ml water).

All the test tubes with positive result (gas formation in the Durham tube) were then selected for second stage of MPN method, the confirmed test method. One loop of sample was taken to streak onto EMB agar plates and after 24 hours incubation, among fruit juice samples we found green metallic sheen suggesting the presence of Escherichia coli only in sample 02 (Table 3 ). Rest of the samples showed growth of coliform bacteria other than Escherichia coli. The presence of Escherichia coli indicates the faecal contamination of the juice probably from contaminated water source or for poor personal hygiene. And from the water samples, we found green metallic sheen suggesting the presence of Escherichia coli only in sample 3 and 14 (Table 4). Rest of the samples showed growth of coliform bacteria other than Escherichia coli.

The presence of Escherichia coli was confirmed by the completed test (Tables $5 \&$ 6). In lactose fermentation broth it showed gas production. Gram staining was also performed to visualize the cell morphology and gram reaction as a part of completed test procedure. After MPN test method applied on fifteen fruit juice and fifteen water samples, it was found out that only one juice sample and two water samples were non-potable. Other samples were potable in the sense that they were free from faecal contaminations. Such result indicates that the overall quality of fresh fruit juices is good. The processing method, maintenance of hygiene, quality of water and ice used here were followed properly which reflected on the results.
As other coliform bacteria was found on EMB media for all of the juice samples as well as water samples (Tables $7 \& 8$ ), we performed biochemical identification of them. After biochemical identification we confirmed the presence of Klebsiella spp., Pseudomonas spp., Proteus app. and Alcaligenes spp. These microorganisms can also cause intestinal disorders. The presence of such bacteria indicates that though the juice preparation procedure was free from faecal contamination, still there are some lacking which should be minimized to protect public health safety.

\section{CONCLUSION}

The overall quality of fresh fruit juices and water is good because only one juice and two water sample was contaminated with Escherichia coli suggesting of faecal contamination. Others were potable according to the absence of the indicator bacteria. The people are becoming more aware about sanitation and hygiene and the quality of processing non-alcoholic beverage items has been increased. But it is needed to be more careful on using water which must be properly purified, and sanitation process should be prioritized more to reduce the number of other contaminating bacteria.

\section{CONFLICT OF INTEREST}

Authors have no conflict of interest.

\section{ACKNOWLEDGEMENT}

I do acknowledge Dr. Rashed Noor, Chairman, Department of Microbiology, Stamford University Bangladesh, for his kind support, encouraging advice and valuable guidance throughout the course of this work.

\section{REFERENCES}

1. Ahmed T, Acharjee M, Rahman MS, Noor R. 2013. Microbiological study of drinking water: Qualitative and quantitative approach. Asian J. Microbiol. Biotech. Env. Sc. 15 (4): 647-654.

2. Ahmet T, Baidya S, Acharjee M, Rahman T. 2013. Qualitative analysis of drinking water through the most probable number (MPN) method. Stamford Journal of Microbiology. 3 (1): 9-16.

TABLE 5. Completed test results for juice

\begin{tabular}{cccc}
\hline Sample no. & $\begin{array}{c}\text { Gas in lactose } \\
\text { fermentation broth }\end{array}$ & Gram reaction & Result \\
\hline 02 & Positive & Gram negative, short rod & Escherichia coli confirmed \\
\hline
\end{tabular}

TABLE 6. Completed test results for water

\begin{tabular}{cccc}
\hline Sample no. & $\begin{array}{c}\text { Gas in lactose } \\
\text { fermentation broth }\end{array}$ & Gram reaction & Result \\
\hline 03 & Positive & Gram negative, short rod & $\begin{array}{l}\text { Escherichia coli confirmed } \\
\text { Escherichia coli confirmed }\end{array}$ \\
\hline
\end{tabular}


TABLE 7. Presence of other gram negative bacteria in the juice samples other than Escherichia coli on EMB media

\begin{tabular}{ccccc}
\hline Sample no. & Proteus spp. & Pseudomonas spp. & Klebsiella spp. & Alcaligenes spp. \\
\hline 01 & + & - & + & - \\
02 & + & - & - & + \\
03 & - & + & - & + \\
04 & - & + & + & + \\
05 & - & - & - & - \\
06 & + & + & - & + \\
07 & - & - & + & - \\
08 & - & + & - & + \\
09 & + & - & - & + \\
10 & - & - & - & - \\
11 & + & + & - & + \\
12 & + & - & - & - \\
13 & + & - & + & + \\
14 & - & - & &
\end{tabular}

TABLE 8. Presence of other gram negative bacteria in the water samples other than Escherichia coli on EMB media

\begin{tabular}{ccccc}
\hline Sample no. & Proteus spp. & Pseudomonas spp. & Klebsiella spp. & Alcaligenes spp. \\
\hline 01 & - & + & - & - \\
02 & - & + & + & - \\
03 & - & - & - & - \\
04 & + & - & + & - \\
05 & + & + & - & + \\
06 & + & + & - & + \\
07 & - & - & + & - \\
08 & - & - & + & - \\
09 & - & + & - & - \\
10 & + & - & - & + \\
11 & - & - & + & - \\
12 & + & + & - & - \\
13 & - & - & + & + \\
14 & - & - & + & - \\
15 & - & & &
\end{tabular}

3. Acharjee M, Jahan F, Rahman F, Noor R. 2013. Bacterial proliferation in municipal water supplied in Mirpur locality of Dhaka City, Bangladesh. Clean - Soil, Air, Water. 41: 1-8.

4. Mahbub KR, Nahar A, Ahmed MM, Chakraborty A. 2011. Quality Analysis of Dhaka WASA drinking water: Detection and biochemical characterization of the isolates. J. Environ. Sci. Natural Res. 4 (2): 41 -49.

5. Nakade DB. 2013. Assessment of bacteriological quality of water in Kolhapur city of Maharashtra,India.Int. Res.j.Enviromental Sci. 2 (2): 63 65.

6. WHO. 2000. Global water supply and sanitation assessment 2000 report.

7. Mead AM, Helm G, Callan P, Atlas RM. 1999. A prospective study of drinking water quality and gastrointestinal diseases. New Eng. J. Med. 245 (9): 224-248.

8. Kamal MMA, Hansen M, Badruzzaman ABM. 1999. Assessment of pollution of the river Buriganga, using a water quality model. Water Sci. Tech. 40 (2): 129-136.

9. Subramania B. 2004. Water quality in South Asia. Asian J. Water Environ. Pol. 1 (1-2): 41-55.

10. Acharjee M, Rahman F, Beauty S, Feroz F, Rahman M, Noor, R. 2012. Microbiological study on supply water and treated water in Dhaka city. Stam. J. Microbial. 1 (1): 42-45. WHO. 1993. Guidelines for drinking water quality. Vol.1, Geneva, World Health Organisation.

11. Cray WCJ, Moon HW. 1995. Experimental infection of calves and adult cattle with Escherichia coli O157:H7. Appl. Environ. Microbiol. 61 (4): 1586-1590.

12. Singh A, Mefeters GA. 1992. Detection method for water borne pathogens. In R. Mitchell (ed.), Environmental microbiology. John Willey and sons Inc., New York.

13. Nahar A, Ahmed MM, Chakraborty A. 2011. A Quality Analysis of Dhaka WASA Drinking Water: Detection and biochemical characterization of the Isolates. J. Environ. Sci. Nat. Res. 4 (2): 41 -49.

14. Munshi SK, Rahman MM, Noor R. 2012. Detection of virulence potential of diarrheagenic Escherichia coli isolated from surface water rivers surrounding Dhaka city. J. Bang. Acad. Sci. 36 (1): 109-122.
15. Noor R, Acharjee M, Ahmed T, Das KK, Paul L, Munshi SK, et al. 2013. Microbiological study of major sea fish available in local markets of Dhaka city, Bangladesh. J. Microbiol. Biotech. Food Sci. 2 (4): 2420-2430.

16. Emde KME, Mao H, Finch GR. 1992. Detection ad occurrence of water borne bacterial and viral pathogens. Water Environ. Ret. 64: 641-47.

17. Geldreich EL. 1992. Water borne pathogens invasions: A case for water quality protection in distribution. Proceedings of American Water Works Associati on. Water Quality Technology Conference.

18. Joklik WK, Willett HP, Amos DB. 1992. Ziusser Microbiology, 20th Edition. Norwalk; Appleton and Lange.

19. Hyson DA. 2011. A comprehensive review of Apples and Apple Components and their relationship to human health. Adv. Nutr. 2: 408-420.

20. Tambekar DH, Jaiswal VJ, Dhanorkar DV, Gulhane PB, Dulhane MN. 2009. Microbiological safety of street vended fruit juices: A case study of Amravati city. Internet Journal of Food Safety. 10: 72-76.

21. FDA. 1999. Fruit morphology and composition. Center for Food Safety and Applied Nutrition United States Food and Drug Administration. Available at: http://vm.cfsan. fda.gov/ comm/ juicback.html. Accessed 06 August 2007.

22. Tasmin F, Hossain MA, Nusrath S, Hossain MK Lopa D, Haque FKM 2010. Quality Assessment of Industrially Processed Fruit Juices Available in Dhaka City, Bangladesh. Mal J Nutr. 16 (3): 431-438.

23. Saenz C, Sepulveda E. 2001. Cactus-pear juices. J Profess Assoc Cactus Develop, 10: 3-10.

24. Franke AA, Cooney RV, Henning SM, Custer LJ. 2005, Bioavailability and antioxidant effects of orange juice components in humans. J Agric. Food. Chem. 53 (13): 5170-8.

25. Basar MA, Rahman SR. 2007. Assessment of microbiological quality of processed fruit juice. Bangladesh Journal of Microbiology. 24 (2): 166-168.

26. Durgesh PM, Ranjana GK, Varsha KV. 2008. Microbiological analysis of street vended fruit juices from Mumbai city, India. Internet Journal of Food Safety. 10: 31-34.

27. Fraternale D, Ricci D, Flamini G, Giomaro G. 2011. Volatile profiles of red apple from Marche Region (Italy). Rec. Nat. Prod. 5 (3): 202-207. 
43. Victorian Government Department of Human Services, Food Safety Unit Melbourne, Victoria. 2005. Microbiological survey of freshly squeezed juices from retail businesses across Victoria. Available at: http://www.health.vic.gov.au/foodsafety. Accessed September 92007.

44. Nicolas B, Razack BA, Yollande I, Aly S, Tidiane OCA, Philippe NA, et al. 2007. Street-Vended Foods Improvement: Contamination Mechanisms and Application of Food Safety Objective Strategy: Critical Review. Pakistan Journal of Nutrition. 6 (1): 1 -10.

45. Oliveira ACG, Seixas ASS, Sousa CP, Souza CWO. 2006 Microbiological evaluation of sugarcane juice sold at street stands and juice handling conditions in São Carlos, São Paulo, Brazil. Cad. Saúde Pública, Rio de Janeiro. 22 (5): 1111 -1114.

46. Durgesh PM, Ranjana GK, Varsha KV. 2008. Microbiological analysis of street vended fruit juices from Mumbai city, India. Internet Journal of Food Safety. 10: 31-34

47. Barro N, Bello AR, Aly S, Ouattara CAT, Ilboudo AJ, Traoré AS. 2006. Hygienic status and assessment of dishwashing waters, utensils, hands and pieces of money from treet food processing sites in Ouagadougou (Burkina Faso). African Journal of Biotechnology. 5 (11): 1107-1112.

48. Al-Jedah, Robinson RK. 2001. Nutritional value and microbiological safety of fresh fruit juices sold through retail outlets in Qatar. Pakistan. J. Nutr. 1: 79-81.

49. Buchaman RL, Edelson SG, Miller RL, Sapers GM. 1999. Contamination of intact apples after immersion in an aqueous environment containing Escherichia coli O157:H7. J. Food Prot. 62: 444-450.

50. Ketema T, Gaddis T, Bacha K. 2008. Microbiological safety of fruit juices served in cafes/restaurants, Jimmy Town, South West Ethopia. Ethiop J Health Sci. 18 (3): 95-100.

51. Sandeep M, Diwakar A, Abhijit G. 2004. Microbiological Analysis of Street Vended Fresh squeezed Carrot and Kinnow-Manderian Juices in Patiala City, India. Internet J. Food safety. 3: 1-3.

52. Johnson, T, Case C. 2010. Laboratory Experiments in Microbiology. Benjamin Cummings, San Francisco.

53. Bej AK, Steffan RJ, DiCesare J, Haff L, Atlas RM. 1990. Detection of coliform bacteria in water by polymerase chain reaction and gene probes. Appl. Environ. Microbiol. 56 (2): 307-314.

54. Tharannum S, Sunitha S, Nithya J, Chandini M, Vanitha J, Manjula TS. 2009. Molecular confirmation of the presence of coliforms in drinking water using polymerase chain reaction. Kath. Uni. J. Sci. Eng. Tech. 5 (2): $130-136$.
28. Malhotra S, Shiva SK, Devi P. 2007. Assessment of bacteriological quality of drinking water from various sources in Amritsar district of northern India. J. Infect. Dev. Ctries. 9 (8): 844-848.

29. Abera S, Zeyinudin A, Kebede B, Deribew A, Ali S, Zemene E. 2011. Bacteriological analysis of drinking water sources. Afr. J. Microbiol. Res. 5 (18): 2638-2641

30. Cappuccino JG, Sherman N. 1996. Microbiology- A laboratory manual. The Benjamin/Cummings Publishing Co., Inc., Menlo Park, California.

31. Alfrad E, Bensons B. 2007. Microbiological Applications. McgrawHill Book Company., New York

32. Yasmin S, Parveen S, Munna MS, Noor R. 2015. Detection of Salmonella spp. and Microbiological Analysis of Milk and Milk Based Products Available within Dhaka Metropolis, Bangladesh. British Microbiology Research Journal. 5 (6): 474-480.

33. Noor R, Uddin MA, Haq MA, Munshi SK, Acharjee M, Rahman MM. 2013. Microbiological study of vendor and packed fruit juices locally available in Dhaka city, Bangladesh. Int Food Res J. 20 (2): 1011-1015.

34. Marjan S, Das KK, Munshi SK, Noor R. 2014. Drug-resistant bacteria pathogens in milk and some milk products. Nutrition \& Food Science. 44 (3): 241-248.

35. Fatema N, Acharjee M, Noor R. 2013. Microbiological profiling of imported apples and demonstration of bacterial survival capacity through in vitro challenge test. Am J Microbiol Res. 1 (4): 98- 04

36. Sultana, B, Anwar F. 2008. Flavonols (kaempferol, quercetin, myricetin) contents of selected fruits, vegetables and medicinal plants. Food Chem. 108 879-884.

37. Uddin MA, Haque HMM, Noor R, 2011. Isolation and Identification of Pathogenic Escherichia coli, Klebsiella spp. And Staphylococcus spp. in Raw Milk Samples Collected from Different Areas of Dhaka City, Bangladesh. Stamford J Microbiol. 1 (1): 19-23.

38. Bhaskar J, Usman M, Smitha S, Bhat GK. 2004. Bacteriological profile of street foods in Mangalore. Indian J. Med. Microbiol. 22: 197-197

39. Mensah, P, Yeboah-Manu D, Owusu-Darko K, Ablordey A. 2002. Street foods in Accra, Ghana: how safe are they? Bull. W. H. O. 80: 546-554.

40. Afroz H, Sultana F, Fakruddin M, Kamrunnahar, Khan ZUM, Datta S 2013. Isolation of Escherichia coli and Staphylocccus aureus from full cream power milk sold under market conditions at Dhaka, Bangladesh and their antibiotic susceptibility. J Adv Sci Res. 4 (3):27-31.

41. WHO, 2002. Food safety and food borne illness. Fact Sheet.

42. Bramley AJ, McKinnon CH. 1990. The microbiology of raw milk.: Elsevier Applied Sci., London. 